\title{
Socioeconomic status as determinant of risk factors for overweight in adolescents
}

\section{Status socioeconômico como determinante de fatores de risco associados com o sobrepeso em adolescentes}

\author{
Rômulo Araújo Fernandes ${ }^{1}$ \\ Diego Giulliano Destro Christofaro ${ }^{2}$ \\ Jefferson Rosa Cardoso ${ }^{3}$ \\ Enio Ricardo Vaz Ronque ${ }^{3}$ \\ Ismael ForteFreitas Júnior ${ }^{4}$ \\ Sandra Satie Kawaguti ${ }^{3}$ \\ Augusto César Ferreira de M oraes ${ }^{5}$ \\ Arli Ramos deOliveira ${ }^{3}$
}

1 Departamento deEducação Física da Universidade do Oeste Paulista. UN OESTE, Presidente Prudente-SP Rodovia Raposo Tavares Km 572, Bairro Limoeiro. 19067-175 Presidente Prudente SP.

diegochristofaro@yahoo.com.br 2 Programa de Pósgraduação em Saúde Coletiva. Universidade Estadual de Londrina-PR.

${ }^{3}$ Programa de Pósgraduação em Educação

Física. Universidade Estadual de Londrina-PR.

${ }^{4}$ Departamento deEducação

Física da U niversidade

Estadual Paulista,

Presidente Prudente-SP.

${ }^{5}$ Escola de M edicina da

USP. Universidade de São

Paulo-SP.
Abstract 0 bjectives: To analyze risk factors for overweight among adolescents grouped in three different socioeconomic levels. M ethods: This cross-sectional study included 1779 adolescents aged 11 to 17 years, grouped according to socioeconomic status (low, middle, and high). Parents reported their own anthropometric data and the adolescents had their anthropometric data taken by trained researchers, and completed three questionnaires. Results: The prevalence of overweight was $16.7 \%, 23.8 \%$, and $26.3 \%$ in low, middleand high socioeconomic status, respectively $(P=$ $0.001)$. In all socioeconomic status, parent's overweight was associated with adolescent overweight (all $\mathrm{P}<0.05)$. The students in both high $(P R=$ $1.90)$ and middle socioeconomic status ( $P R=2.00)$ from private schools were associated with overweight, and the students from low socioeconomic level to sedentary behavior $(P R=2.25)$ and high ingestion of fried food ( $P R=2.35)$. Conclusion: In each socioeconomic status the overweight was associated with different risk factors in different ways, except for parents overweight. Key words Adolescents, Overweight, Socioeconomic status
Resumo Objetivo: Analisar osfatores derisco para o sobrepeso entre adolescentes agrupados em três níveis econômicos diferentes. M étodos: Estudo transversal queincluiu 1779 adolescentes com idadede 11-17 anos, agrupados de acordo com a condição econômica (baixo, médio e alto). Os pais reportaram seus próprios dados antropométricos e os adolescentes tiveram seus dados antropométricos aferidos por avaliadores treinados, e também responderam a três questionários. Resultados: A prevalência de sobrepeso foi de $16.7 \%, 23.8 \%$ e $26.3 \%$ nas classes econonômicas baixa, média e alta, respectivamente $(P=0.001)$. Em todas as condiç̃eses econômicas, o sobrepeso dos pais foi associado com o sobrepeso dos filhos $(P<0.05)$. Os estudantes de classes econômicas média e alta $(\mathrm{RP}=2.00)$ de escolas privadas foram associados com o sobrepeso, e estudantes de baixo nível sócioeconômico com comportamento sedentário ( $R P=$ $2,25$ ) ealta ingestão defrituras ( $P R=2.35)$. Conclusão: Em cada nível socioeconômico o sobrepeso é associado com diferentes fatores de risco de diferente formas, exceto para pais com sobrepeso. Palavras-chave Adolescentes, Sobrepeso, Status socioeconômico 


\section{Introduction}

Theprevalence of overweight during childhood and adolescence is increasing rapidly and, its association with several risk factors for chronic diseases has created a serious public health problem ${ }^{1-6}$.

The excess of body fat has a multifaceted development and it is known that behavioral factors (sedentarism and inadequate food intake) play an important role on its alarming rise. Relations also have been madeto factors in thefamily nucleus (parents' overweight/schooling, family size/income), which despite being controversial in origin (behavioral or genetic), constitute one of the most important agents associated to excess of body fat.

Studies have shown that overweight is essentially observed in lower socioeconomic status (SES) in developed countries, whilein developing ones it is morefrequent among thehigher SES ${ }^{3,4}$. Additionally, researches have produced solid evidences that, in recent decades, the burden of overweight is shifting toward the poor population in developing countries ${ }^{3,4,7}$. This increasing trend is concrete but the main risk factors associated to overweight at each SES is not completely understood. The purpose of the present study was to analyze risk factors for overweight in adolescents from three different socioeconomic status (SES).

\section{M ethods}

This cross-sectional study was carried out in the city of PresidentePrudente(Human D evelopment Index $=0.846$ ) in the Southeast region of Brazil, from July through October, 2007. The city has approximately $37000^{8}$ students from 11 to 17 years old, distributed in 118 primary and secondary schools. The sample size of 1779 subjects comprised adolescents of both genders, and was estimated by means of an assumed overweight prevalence of $28.6 \%$ (error of $2.1 \%$ ), with a power of $80 \%$, and an alpha error of $5 \%$. Of the 118 schools, six were selected randomly to participatein thestudy. In each school, all students were invited to participate and received an informed written consent form, which was filled out by one of the parents/guardians and the student, before participating in the survey. From the 2200 eligible students, 1779 participated in the study ( response rate $=80 \%$ ). The study was approved by the Ethics Committee on Human Experimentation of Sao Paulo State University.
In the selected schools, approximately $99.5 \%$ (2190) of all students participated in physical education classes. Thus, the anthropometric data were collected during physical education class. $\mathrm{H}$ eight and body mass were determined by standard anthropometric methods 9 . The height was measured to thenearest $0.1 \mathrm{~cm}$ and the body mass to the nearest $0.1 \mathrm{~kg}$, with a wood stadiometer and a calibrated portable digital scale, respectively (wearing light clothes and no shoes). Thebody mass index (BMI $\left.\left[\mathrm{kg} / \mathrm{m}^{2}\right]\right)$ was calculated and the cut-off values for age and gender proposed by Cole et $a .^{10}$ was used to classify the adolescents as eutrophic or overweight/obese.

Theadolescents filled out physical activity/sedentary, eating behaviors and SES questionnaires, which were administered by a trained researcher. Physical activity and sedentary behavior during leisuretimewereassessed using the questionnaire developed by Baecke et al. ${ }^{11}$. According to this questionnaire for sports activities, the adolescent was considered regularly engaged in sports if played any organized sport of moderate to vigorous intensity at least 3-4 hours per week in the three months or more, prior to the present study. Data regarding leisure time activities (walking, cycling, and TV watching) werealso collected according to the Baecke questionnaire ${ }^{11}$. The frequency (never; seldom; sometimes; often; very often) of these activities were collected and grouped in three dichotomized variables for sedentary/activebehaviors: TV watching (YES = very often; $\mathrm{NO}=$ never, seldom, sometimes, or often); walking and cycling (YES = never; $\mathrm{NO}=$ seldom, sometimes, often, or very often).

Data about eating behaviors were collected through a structured questionnaire, applied by the same researcher. The questionnaire involved four questions about frequency of some food consumption (fruits, vegetables, snacks, fried foods) in thelast week (0/day; 1-2/days; 3-6/days; all days). The answers " $0 /$ day" for fruits and vegetables, and "all days" for snacks and fried foods were adopted as risks for overweight.

Data of family SES were obtained using a standardized questionnaire (Brazilian criteria of economic classification of the Brazilian Association of Research Institutes) ${ }^{12}$ covering the parents' education, presence/absence and number of domestic appliances and vehicles, and rooms in the adolescents' home. Through a specific score attributed by the questionnaire, the family was classified in one of seven categories (A1 [the wealthiest], A2, B1, B2, C, D and E [the poorest]). The sample was grouped into three SES according 
family income: High SES (H-SES: categories A1 and A2), M iddle SES (M-SES: categories B1 and B2) and Low SES (L-SES: categories C, D and E). Although school type can be a proxy of SES, in Brazil thereis an association between overweight and private school (higher occurrence), as well as the students from public and private schools present different behaviors related to physical activity and food intake. Thus, the type of school (i.e., private school) was also treated as risk factor for overweight among the adolescents.

Parents were invited to participate by letter, and, at home, they filled out a questionnaire in which they reported their own weight, height, school level and number of siblings living in the adolescent's home. Low level of parent education ( $\leq 15$ years) and overweight (BMI $\geq 25 \mathrm{~kg} / \mathrm{m}^{2}$ ) were treated as family risks for overweight. In developing countries, the smaller family size is associated with higher occurrence of overweight; thus, none/one sibling living in the same home was also treated as indicator of it.

To analyze the consistency of the parent's reported data, thirty parents were randomly selected and invited to participatein an interview at school, where a researcher took anthropometric measures (body weight and height). The agree ment degree (Kappa statistic [k]) of the BM I nutritional status (dichotomized variables: "yes" or "not" for BMI e" $\left.25 \mathrm{~kg} / \mathrm{m}^{2}\right)$ between the two measures was high $(k=0.85)$. Additionally, to analyzethe consistency of the adolescent's reported data, one hundred and seventy adolescents were randomly selected and invited to participate in an interview at school, wherea researcher readministered the same questionnaires. The data's agreement level was high (dichotomized variables: "yes" or "not" for both (i) the fist answer in PA [ $k=0.85$ ] / eating behaviors [fruits: $k$ $=0.75$; vegetables: $\mathrm{k}=0.75$; snacks: $\mathrm{k}=0.76$; fried foods: $k=0.76]$ and (ii) the same group of family SES $[k=0.87])$.

The chi-squared test $\left(\chi^{2}\right)$ was used initially to verify association between overweight and all analyzed risk factors. Poisson Regression with robust variance (prevalence ratio [PR] and 95\% confidence interval $[95 \% \mathrm{CI}]$ ) was also applied. The variables significantly associated in univariate model $(P<0.05)$ remained in thefinal models (all entered simultaneously). The Kappa statistic (k) indicated the agreement level to the categorical variables. The STATA 8.0 software (Stata Inc., College Station, TX, USA) was used for all data analysis. Thesignificancelevel was set at $p<0.05$.
Results

The obesity rate in the study sample was $6.1 \%$ and theoverweight ratewas $16.8 \%$. In theoverall sample, gender was associated with overweight ( male $=26.7 \%$ and female $=19.6 \% ; P=0.001$ ), as well as studying in private schools ( $P R=1.67$ [1.37-2.05]). The sample was organized in three groups based on theSES, and the combined overweight prevalence observed was: $\mathrm{H}-\mathrm{SES}=26.3 \%$, $M-S E S=23.8 \%$ and L-SES $=16.7 \%(P=0.001)$.

In univariate model, overweight was associated with number of siblings in the M-SES (PR = 1.30 [1.00-1.74]), type of school in both H-SES $(P R=1.58[1.09-2.28])$ and $M-S E S(P R=1.76$ [1.30-2.37]). In all SES, mother/both parents' overweight was associated with overweight (Table 1).

In the eating behavior variables (Table 2), non-habitual consumption of fruits was associated with overweight in the H-SES (PR = 1.31 [1.00-2.45]), as well as excessive fried food consumption in the L-SES (PR = 1.14 [1.03-1.93]). Among all sedentary behaviors during leisure time analyzed, only in the L-SES, the "never cycling" variable presented association ( $P R=1.67$ [1.01-2.78]) with adolescent overweight.

In additional analysis, gender was included as a confounder variable and there was a significant association with overweight only in the $\mathrm{H}$ SES (PR $=1.38$ [1.00-1.96]) and therefore, in the highest SES, the male gender was included in the multivariate model.

All variables with $P<0.05$ were added simultaneously in the multivariate model for Poisson regression (Table 3), which indicated that independently of SES, parents' overweight was strongly associated with adolescents' overweight. The data showed that the type of school maintained its association in the two highest SES, as well as the behavioral risk factors in the L-SES. There was no association with lower number of siblings in the final model.

\section{Discussion}

The present study verified that different risk factors for overweight are associated with SES, and strongly related to parent's overweight, independently of SES.

Overall overweight prevalence found in the studied adolescents (22.9\%) was higher than the observed in European adolescents $(15 \%)^{13}$, and 
Table 1. Crude prevalence ratio for family risk factors associated to overweight and obesity on adolescents (Presidente Prudente. Brazil).

\begin{tabular}{|c|c|c|c|c|c|c|}
\hline \multirow{2}{*}{ Variables } & \multicolumn{2}{|c|}{ L-SES $(n=400)$} & \multicolumn{2}{|c|}{ M-SES $(n=876)$} & \multicolumn{2}{|c|}{ H-SES $(n=503)$} \\
\hline & $\mathrm{N}(\%)$ & PR $(95 \% \mathrm{Cl})$ & $\mathrm{N}(\%)$ & PR $(95 \% \mathrm{Cl})$ & $\mathrm{N}(\%)$ & PR $(95 \% \mathrm{Cl})$ \\
\hline \multicolumn{7}{|l|}{ Number of siblings } \\
\hline$\geq 2$ siblings & 35 (15.3) & 1.00 & $76(20.1)$ & 1.00 & $44(25)$ & 1.00 \\
\hline$\leq 1$ sibling & $31(20.3)$ & $1.23(0.7-2.0)$ & $131(27.7)$ & $1.30(1.0-1.7)$ & $87(28.7)$ & $1.07(0.7-1.5)$ \\
\hline \multicolumn{7}{|l|}{ Type of school } \\
\hline Public school & $65(16.8)$ & 1.00 & $147(20.8)$ & 1.00 & $41(19.6)$ & 1.00 \\
\hline Private school & $1(11.1)$ & $0.66^{*}(0.1-4.7)$ & $60(36.6)$ & $1.76(1.3-2.3)$ & $90(31)$ & $1.58(1.1-2.2)$ \\
\hline \multicolumn{7}{|l|}{ Parents' schooling } \\
\hline Father (<15 years) & 65 (17.4) & 1.00 & $174(24.5)$ & 1.00 & $62(28.4)$ & 1.00 \\
\hline Father ( $\geq 15$ years) & $1(11.1)$ & $0.65^{*}(0.1-4.7)$ & $33(29.5)$ & $1.27(0.8-1.8)$ & $69(25.6)$ & $0.94(0.6-1.3)$ \\
\hline M other (<15 years) & $65(16.9)$ & 1.00 & $179(25)$ & 1.00 & $63(29.5)$ & 1.00 \\
\hline M other ( $\geq 15$ years) & $1(16.7)$ & $1.00 *(0.1-7.2)$ & $28(23.1)$ & $0.96(0.6-1.4)$ & $68(24.7)$ & $0.86(0.6-1.2)$ \\
\hline \multicolumn{7}{|l|}{ Parents' overweight } \\
\hline None & $4(4.7)$ & 1.00 & $10(6.9)$ & 1.00 & $13(17.5)$ & 1.00 \\
\hline Father $\left(\mathrm{BMI} \geq 25 \mathrm{~kg} / \mathrm{m}^{2}\right)$ & $8(6.8)$ & $1.44(0.7-3.1)$ & $70(21.8)$ & $2.43(1.1-2.8)$ & $50(21.7)$ & $1.17(0.7-2.4)$ \\
\hline M other $\left(\mathrm{BMI} \geq 25 \mathrm{~kg} / \mathrm{m}^{2}\right)$ & $16(14.5)$ & $3.05(2.2-11)$ & $23(22.3)$ & $2.59(1.3-2.7)$ & $13(25)$ & $1.52(1.0-2.8)$ \\
\hline Both (BMI $\geq 25 \mathrm{~kg} / \mathrm{m}^{2}$ ) & $38(24.3)$ & $6.22(1.4-27)$ & $104(33.5)$ & $3.60(1.2-2.5)$ & $55(37.4)$ & $2.07(1.0-2.9)$ \\
\hline
\end{tabular}

*- Fisher'sExact Test- BMI = Body mass index- $\mathrm{H}$-SES= Highest socioeconomic status- $\mathrm{M}$-SES= $\mathrm{M}$ iddle socioeconomic status- L-SES=Lowest socioeconomic status- PR = Prevalence ratio- CI 95\%=Confidence interval of $95 \%$.

Table 2. Crude prevalence ratio for behavior risk factors related to overweight and obesity in adolescents (Presidente Prudente. Brazil).

\begin{tabular}{|c|c|c|c|c|c|c|}
\hline \multirow{2}{*}{ Variables } & \multicolumn{2}{|c|}{ L-SES $(n=400)$} & \multicolumn{2}{|c|}{ M-SES $(n=876)$} & \multicolumn{2}{|c|}{$\mathrm{H}-\mathrm{SES}(n=503)$} \\
\hline & N (\%) & PR $(95 \% \mathrm{Cl})$ & N (\%) & PR $(95 \% \mathrm{Cl})$ & $\mathrm{N}(\%)$ & PR $(95 \% \mathrm{Cl})$ \\
\hline \multicolumn{7}{|l|}{ Food intake } \\
\hline Snacks (< 7 days) & 59 (19.3) & 1.00 & $171(26.3)$ & 1.00 & $107(30.5)$ & 1.00 \\
\hline Snacks (> 7 days) & $7(8.5)$ & $0.75(0.4-1.4)$ & $36(18)$ & $0.71(0.5-1.0)$ & $24(18.6)$ & $0.93(0.6-1.3)$ \\
\hline Fried foods ( $<7$ days) & $51(16.7)$ & 1.00 & $174(25.5)$ & 1.00 & $117(29.7)$ & 1.00 \\
\hline Fried foods (> 7 days) & $15(21.7)$ & $1.14(1.0-1.9)$ & $33(19.9)$ & $0.82(0.5-1.2)$ & $14(16.5)$ & $0.59(0.3-1.2)$ \\
\hline Vegetables (> 1 day) & $60(17.2)$ & 1.00 & $187(25.1)$ & 1.00 & $117(27.7)$ & 1.00 \\
\hline Vegetables (none/day) & 6 (17.6) & $1.06(0.4-2.4)$ & $20(19.6)$ & $0.81(0.5-1.3)$ & $14(25.9)$ & $0.99(0.5-1.7)$ \\
\hline Fruits (> 1 day) & $62(17.8)$ & 1.00 & $197(25)$ & 1.00 & $116(26.3)$ & 1.00 \\
\hline Fruits (none/day) & 4 (10.8) & $0.71(0.2-2.2)$ & $10(14.9)$ & $0.89(0.8-1.2)$ & $15(38.5)$ & $1.31(1.0-2.4)$ \\
\hline \multicolumn{7}{|l|}{ Sports } \\
\hline N ot engaged & 40 (18.4) & 1.00 & $128(25.5)$ & 1.00 & $108(29.2)$ & 1.00 \\
\hline Regularly engaged & $26(14.7)$ & $0.98(0.3-2.9)$ & $78(21.2)$ & $0.75(0.3-1.5)$ & $23(18)$ & $0.83(0.3-1.8)$ \\
\hline \multicolumn{7}{|l|}{ LTB } \\
\hline Watch TV (No) & 38 (19.2) & 1.00 & $138(25.5)$ & 1.00 & $95(25.5)$ & 1.00 \\
\hline Watch TV (Yes) & $28(14.4)$ & $0.74(0.4-1.2)$ & $69(21.2)$ & $0.85(0.6-1.1)$ & $36(28.8)$ & $1.13(0.7-1.6)$ \\
\hline Walk (Yes) & 49 (16.1) & 1.00 & $179(25.3)$ & 1.00 & $117(27.1)$ & 1.00 \\
\hline Walk (No) & $17(20.2)$ & $1.25(0.7-2.1)$ & $28(18.1)$ & $0.72(0.4-1.1)$ & $14(21.2)$ & $0.79(0.4-1.3)$ \\
\hline Cycle (Yes) & $43(14.4)$ & 1.00 & $165(25)$ & 1.00 & $100(27.7)$ & 1.00 \\
\hline Cycle (No) & $23(24.2)$ & $1.67(1.0-2.7)$ & $42(20.3)$ & $0.82(0.5-1.1)$ & 31 (23.3) & $0.85(0.5-1.2)$ \\
\hline
\end{tabular}

$\mathrm{H}$-SES= Highest socioeconomic status- $\mathrm{M}$-SES= M iddle socioeconomic status- L-SES= Lowest socioeconomic status- PR= Prevalence ratio- $\mathrm{Cl}$ $95 \%=$ Confidence interval of $95 \%$ - LTB $=$ leisure time behaviors. 
Table 3. Poisson regression for association between overweight and family/behavioral risk factors in adolescents (Presidente Prudente. Brazil).

\begin{tabular}{lccccc}
\hline \multicolumn{1}{c}{ Risk factors } & $\boldsymbol{\beta}$ & S.E. & $\chi^{2}$ & $P$ & PR $(95 \% \mathrm{Cl})$ \\
\hline H-SES & & & & & \\
$\quad$ Gender (male) & 0.517 & 0.262 & 3.892 & 0.049 & $1.67(1.00-2.80)$ \\
$\quad$ Private school & 0.642 & 0.267 & 5.786 & 0.016 & $1.90(1.12-3.20)$ \\
$\quad$ Fruits (none day) & 0.590 & 0.362 & 2.659 & 0.103 & $1.80(0.88-3.66)$ \\
$\quad$ Parents' overweight (Both) & 0.707 & 0.263 & 7.219 & 0.007 & $2.02(1.21-3.39)$ \\
M-SES & & & & & \\
$\quad$ Private school & 0.674 & 0.236 & 8.135 & 0.004 & $1.96(1.23-3.11)$ \\
$\quad$ < I sibling & 0.207 & 0.199 & 1.082 & 0.298 & $1.23(0.83-1.81)$ \\
$\quad$ Parents' overweight (Both) & 0.616 & 0.190 & 10.486 & 0.001 & $1.85(1.27-2.68)$ \\
L-SES & & & & & \\
$\quad$ Fried foods (> 7 days) & 0.860 & 0.460 & 3.463 & 0.049 & $2.36(1.00-5.85)$ \\
$\quad$ Cycle (No) & 0.817 & 0.410 & 3.965 & 0.046 & $2.26(1.01-5.05)$ \\
$\quad$ Parents' overweight (Both) & 1.205 & 0.400 & 9.064 & 0.003 & $3.33(1.52-7.31)$ \\
\hline
\end{tabular}

S.E. = standard error- $\mathrm{H}-\mathrm{SES}=\mathrm{H}$ ighest socioeconomic status- M-SES= M iddle socioeconomic status- L-SES= Lowest socioeconomic status- PR = Prevalence ratio- $\mathrm{Cl} 95 \%=$ Confidence interval of $95 \%$.

much higher than the observed in Brazilian adolescents from a random nationally representative sample developed in 1996-1997 (12.6\%) Previous studies 3,4 in developing countries have reported that the overweight is more predominant in $\mathrm{H}$-SES than in other socioeconomic status, agreeing with our findings, since a positive association was observed between higher SES and elevated overweight presence. M oreover, the prevalencefound in theL-SES (16.7\%) is much higher than that observed in the same SES in 19961997 (6.9\%) among Brazilian adolescents ${ }^{3}$. These data also corroborates with previous studies indicating that among adolescents, even in thelowest SES, the burden of nutritional problems is shifting from deficien cy to excess energy intake.

Regular physical activity/sports activities play an important rolein obesity prevention ${ }^{14,15}$. H owever, in other epidemiological studies ${ }^{16-18}$, in all SES, the indicator of physical activity presented no significant association with overweight. Likewise, among European adolescents, Ekelund et al. ${ }^{13}$ found that only sedentary behavior (TV viewing) was associated with body fatness, while physical activity was associated with other metabolic risk factors. Furthermore, in the L-SES, the sedentary behavior during leisure time "never cycling" was associated with overweight, which also is in agreement with previous data indicating that the amount of leisure time activities is low, especially in adolescents from lowest SES ${ }^{18}$.
Therefore, this data indicate that preventivestrategies should target not only the physical activity practice, but also the decrease of the timespent in sedentary behaviors.

Independently of SES, the parents' overweight was a common characteristic observed, indicating that this could be considered the most important predictor for adolescent overweight. This association havealso been found in several studies ${ }^{16,17,19,20}$. Furthermore, it also indicates that the parental obesity can behighly influenced by behavioral variables. In this matter, the mother is more responsible due to her closer involvement in the children's growth process and food intake. Thus, unhealthy mother behaviors such as inadequate food intake tend to be adopted by children ${ }^{20,21}$.

The low fiber intake among adolescents ${ }^{22,23}$ is associated with obesity ${ }^{22}$. In adolescents from $\mathrm{H}$ SES, the low frequency of fruit intake (important source of fiber) was associated with overweight and, similar to other study ${ }^{24}$, the present study found that the excessive intake of fried food was higher among overweight adolescents from L-SES. These associations corroboratewith previous findings, where, foods with high energy density, were associated with overweight in the L-SES, and are, usually, tasteful and less expensive ${ }^{25}$, facilitating their access among subjects from this specific SES.

$M$ ale gender was associated with overweight in $\mathrm{H}$-SES. This data is in agreement with another Brazilian research, where in contrast to men, 
whose rate of overweight has increased in all income groups, women from $\mathrm{H}$-SES showed a decrease in overweight from 1987 to 19977.

The type of school was associated with overweight among theadolescents of both M-SES and $\mathrm{H}$-SES. This association was also found in other studies ${ }^{18,19}$, which attributed the overweight to the higher income of the students. Furthermore, unheal thy food intake during the school break time ${ }^{18}$ and higher blood pressure/total cholesterol ${ }^{26}$ are more common among students from private schools. On theother hand, Veugelers and Fitzgerald $^{27}$ found that, early elementary schools, with healthy eating habits and physical activity programs, can establish healthy behaviors in the early age period. Therefore, the present study indicates that obesity prevention programs, independently of SES, should be focused on schools.

Despitethe positiveaspects of this study, such as reliability measures, random selection of the schools and sample, some limitations must be recognized. The main limitation was the crosssectional design, since it did not allow the determination of causality, but only the exploration of an association between obesity and its different risk factors.

In summary, it is possible to conclude that overweight is more frequent in $\mathrm{H}$-SES, but has high prevalence in all SES and, independently of SES, parents' overweight (mainly mother's overweight) constitutes the main risk factor associated with overweight among these adolescents. Furthermore, it was observed that behavioral risk factors for overweight vary considerably among different SES, indicating that this phenomenon assumes its own unique characteristics depending on the different contexts in which it may be analyzed, suggesting that future strategies to combat obesity should take into account the SES differences.

\section{Collaborators}

RA Fernandes was the main responsible for collection, analysis and interpretation of data, and also drafting the manuscript; JR Cardoso and DGD Christofaro has been involved in analysis and interpretation of data and also in critical revision of the paper; ERV Ronque, IF Freitas Júnior, SS Kawaguti, ACF de Moraes and AR de Oliveira had been involved in revising the manuscript critically for important intellectual content.

\section{Acknowledgements}

Coordenadoria de Aperfeiçoamento do Pessoal de Ensino Superior (CAPES) for the financial support. 


\section{References}

1. Chenoweth $D$, Leutzinger J. The economic cost of physical inactivity and excess weight in American adults. J Phys Act Health 2006; 3(2):148-163.

2. Cardoso L de O, Engstrom EM, Leite IC, Castro IR. Fatores socioeconômicos, demográficos, ambientais e comportamentais associados ao excesso de peso em adolescentes: uma revisão sistemática da literatura. Rev Bras Epidemiol 2009; 12(3):378-403.

3. Wang Y, M onteiro C, Popkin BM. Trends of obesity and underweight in older children and adolescents in the United States, Brazil, China, and Russia. Am J Clin Nutr 2002; 75:971-977.

4. Veiga GV, Cunha AS, Sichieri R. Trends in overweight among adolescents living in the poorest and richest regions of Brazil. Am J Public Health 2004; 94:.1544-1548.

5. Chen W, Berenson GS. M etabolic syndrome: definition and prevalence in children. J Pediatr (Rio J) 2007; 83(1):1-3.

6. Ferreira AP, Oliveira CE, França NM. Metabolic syndrome and risk factors for cardiovascular disease in obese children: the relationship with insulin resistance (HOM A-IR). J Pediatr (Rio J) 2007; 83(1):21-26

7. Monteiro CA, Conde WL, Popkin BM. Incomespecific trends in obesity in Brazil: 1975-2003. Am J Public Health 2007; 97(10):1808-1812.

8. Instituto Brasileiro de Geografia e Estatística. (IBGE). 2008. [acessado 2010 ago 05]. Disponível em: http://www.ibge.gov.br/cidadesat/default.php

9. Gordon CC, Chumlea WC, Roche AF: Stature, recumbent length and weight. In: Lohman TG, Roche AF, Martorel R, editors. Anthropometric standardization reference manual. First ed. Champaign: $\mathrm{Hu}$ man Kinetics Books; 1988. p. 3-8.

10. Cole TJ, Bellizzi MC, Flegal KM, Dietz WH. Establishing a standard definition for child overweight and obesity worldwide: international survey. BM J 2000; 320(7244):1- 6.

11. Baecke JA, Burema J, Frijters JE. A short questionnaire for the measurement of habitual physical activity in epidemiological studies. Am J Clin Nutr 1982; 36(5):936-942.

12. Associação Brasileira de Empresas de Pesquisa. Critério de Classificação Econômica Brasil (CCEB); 2003. [acessado 2010 ago 05]. Disponível em: http:/ /www.abep.org/codigosguias/ABEP_CCEB.pdf

13. Ekelund $U$, Brage $S$, Froberg $K, H$ arro $M$, Anderssen $S A$, Sardinha LB, Riddoch C, Andersen LB. TV viewing and physical activity are independently associated with metabolic risk in children: The European Youth Heart Study. Plos Med 2006; 3(12):2449-2457.

14. Ara I, Vicente-Rodriguez G, Jimenez-Ramirez J, Dorado C, Serrano-Sanchez JA, Calbet JA. Regular participation in sports is associated with enhanced physical fitness and lower fat mass in prepubertal boys. Int J O bes 2004; 28(12):1585-1593.
15. Jakicic JM, Otto AM. Physical activity considerations for the treatment and prevention of obesity. Am J Cin Nutr 2005; 82(Supl. 1):226-229.

16. Silveira $D$, Taddei JA, Escrivão $M A$, Oliveira $F L$, Ancona-Lopez F. Risk factors for overweight among Brazilian adolescents of low-income families: a casecontrol study. Public Health Nutr 2006; 9(4):421-428.

17. Monteiro P, Victora C, Barros F. Social, familial, and behavioral risk factors for obesity in adolescents. Rev Panam Salud Publica 2004; 16(4):250-258.

18. Nunes MMA, Figueiroa JN, Alves JG. Overweight, physical activity and food habits in adolescents from different economic level, Campina Grande (PB). Rev Assoc M ed Bras 2007; 53(2):130-134.

19. Oliveira AM, Oliveira AC, Almeida MS, Oliveira $N$, Adan L. Influence of the family nucleus on obesity in children from northeastern Brazil: a cross-sectional study. BM C Public Health 2007; 7:235-245.

20. M arins VM, Almeida RM, Pereira RA, de Azevedo Barros MB. The relationship between parental nutritional status and overweight children/adolescents in Rio de Janeiro, Brazil. Public Health 2004; 118(1):43-49.

21. Ortega FB, Ruiz JR, Sjostrom M. Physical activity, overweight and central adiposity in Swedish children and adolescents: the European Youth Heart Study. Int J Behav Nutr Phys Act 2007; 4:61.

22. Vitolo M R, Campagnolo PD, Gama CM. Factors associated with a risk of low dietary fiber intake in adolescents. J Pediatr (Rio J) 2007; 83(1):47-52.

23. Neutzling M B, Araújo CL, Vieira M. de F, Hallal $P C$, M enezes AM. Frequency of high-fat and lowfiber diets among adolescents. Rev Saude Publica 2007; 41(3):336-342.

24. Guedes DP, Guedes JE, Barbosa DS, de Oliveira JA, Stanganelli LC. Cardiovascular risk factors in adolescents: biological and behaviors indicators. Arq Bras Cardiol 2006; 86(6):439-450.

25. Drewnowski A, Specter SE. Poverty and obesity: the role of energy density and energy costs. Am J Clin Nutr 2004; 79(1):6-16.

26. Scherr $C, M$ agalhães $C K$, Malheiros W. Lipid profile analysis in school children. Arq Bras Cardiol 2007; 89(2):65-70.

27. Veugelers PJ, Fitzgerald AL. Effectiveness of school programs in preventing childhood obesity: a multilevel comparison. Am J Public Health 2005; 95(3): 432-435.

Artigo apresentado em 06/06/2010

Aprovado em 26/07/2010

Versão final apresentada em 05/08/2010 